Historic, Archive Document

Do not assume content reflects current scientific knowledge, policies, or practices. 




\section{PAKRO SEEDTAPE}

INDEX

What people have done with Pakro Seedtape . . 23

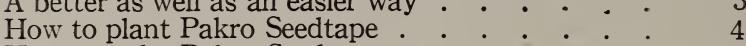

How to order Pakro Seedtape .. . . . . . . . . 4

Special introductory Seedtape offers . . . . . 21-22

Pakro Brand garden seed (loose) . . . . . . . . 23-24

\section{PAKRO SEEDTAPE VEGETABLES}

Cabbage $\div \div \div \div$

Carrots . . . . . . . . . . . . . 7

Celery . . . . . . . . . . . . . 5

Endive . . . . . . . . . . . . . . 7

Kohlrabi . . . . . . . . . . . . . 8

Leek . . . . . . . . . . . . . . 8

Lettuce . . . . . . . . . . . . . . . . . . . 59

Onion . . . . . . . . . . . . . 10

Parsley . . . . . . . . . . . . . . 8

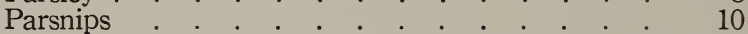

Pepper . . . . . . . . . . . . . . 11

Radish . . . . . . . . . . . . . . 12-13

Spinach $\div \div \div \quad \cdot 511$

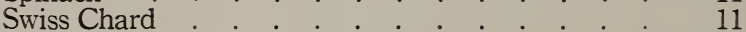

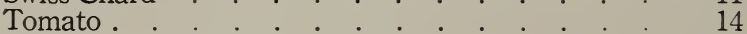

Turnip . . . . . . . . . . . . . . . . . 13

PAKRO SEEDTAPE FLOWERS

Alyssum . . . . . . . . . . . . . . . 15

Aster . . . . . . . . . . . . . . 15

Balsam . . . . . . . 16

Candytuft . . . . . . . . . . 16

Corn Flower . . . . .

Forget-me-not . . . . . . . . . . . . 17

Hollyhock . . . . . . . . . . . . . 17

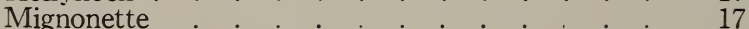

Morning Glory . . . . . . . 18

Pansy . . 18

Phlox Drummondii ; , , , 18

Pinks . . . . . . . . . . . . 19

Poppy . . . . . . . . . . . . . . 19

Salvia . . $\cdot . \cdot 20$

Stocks . . . . . . 20

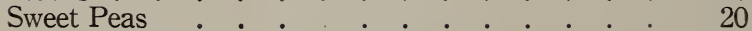




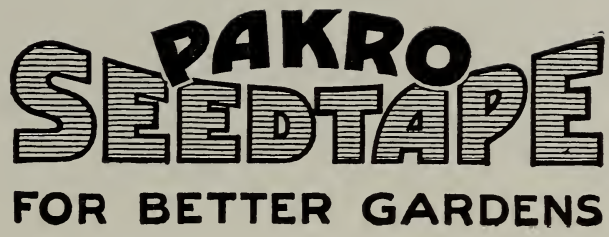

The Easiest-Most Economical-Most

Sensible-Quickest-Most Certain

of Good Results Way in the

World to Plant YOUR

Home Garden

\section{AMERICAN SEEDTAPE CO. \\ 71 WEST 23rd STREET \\ NEW YORK CITY}

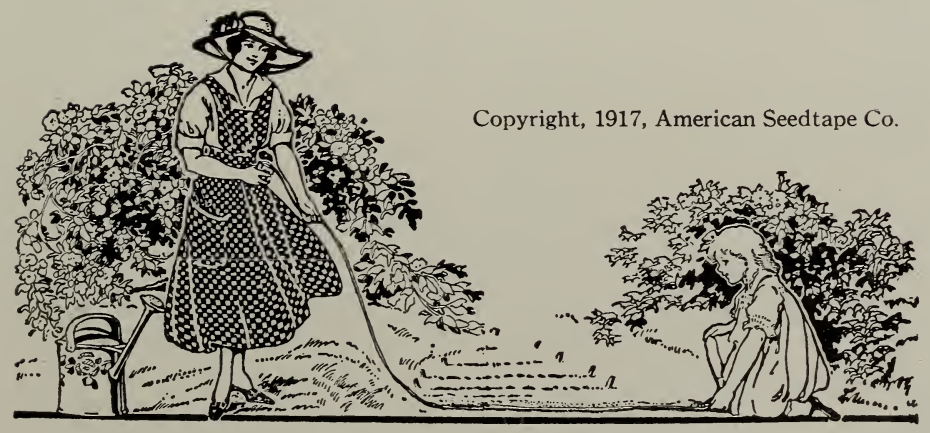




\section{People in all parts of the Country have ob- tained better gardens from the use of}

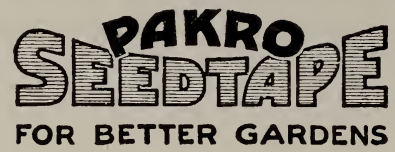

Pakro is not a novelty or a fad. It is the greatest scientific improvement in seed planting evolved in years. You should surely prove this to your own satisfaction and delight by having a Pakro garden this year.

E. J. Kyle, Dean of the Agricultural College of Texas, tells of results obtained from Pakro Seedtape at the college.

"All the Seedtape planted did exceptionally well. The plants made a splendid appearance and the stand was especially good."

The Manager of the San Diego Model Farm at the Panama International Exposition writes:

"We were very much pleased with the results from Pakro Seedtape. The seeds themselves were of high quality and the germination was all that could be desired. The necessity for thinning out is eliminated and an even growth is assured. There is a great saving in labor and expense."

\section{A Few of Several Thousand Pakro Testimonials}

"Am pleased to report the seedtape furnished me was about perfect as could possibly be." - St. Mary's Rectory, J. Woods, Pastor, Le Sueur Center, Minn.

"We had splendid success with seedtape. A good yield and so easy to plant." -J. W. Unstaltd, Bristol, Tenn.

"I liked the seedtape fine. It is not only easy to plant, but every seed grows." -R. Wilcox, Masardis, Me.

"Results fine, Vegetables were earlier and larger. Will use seedtape next season both for results and because they are easier to plant." - Mrs. F. W. Shallish, 854 So. Glenwood Ave., Springfield, Ill.

"I have had great success with seedtape. Very simple to plant, no bother of thinning out plants, and an easy matter to control the weeds. The results were crops in abundance." - Wm. Seims, Adams Corners, Putnam Co., New York.

"I used the seedtape and it is a very good thing and will send you an order in the spring for more. It is a great help to the farmers in planting small seeds. Please send me your seed book in the spring." - Harry L. Smith, Hull's Cove, Me.
"I was very well pleased with the seeds received from you, never saw seed grow as well. All my neighbors were much surprised to see seeds planted in the Tape and you will receive many orders from Batesville next year." - E. C. Timmermann, Batesville, Ind.

"In your Seedtape Arrangement I have found all that it was recommended to $b$ : The success I have had in Garden produc tion was wonderful. I am only desiring of you a Catalog, so I can send for arnother supply for next Spring." - Dr. W. R. Richardson, 47 Oliver Street, Winchester, Ky.

"The same amount of seed goes twice as far as other kinds, besides saving your back. I shall always use seedtape and will tell others about it also."-Mrs. Wm. Behringer, Ann Arbor, Mich.

"I find that seedtape grows quicker than other seeds. And that there is not so much trouble and worry to plant it." Miss Ethel Bowman, R. R. 5., Troy, Ohio.

"We have used the seedtape for past three years, with very good success." -E. L. Eavey, Keedysville, Md. 


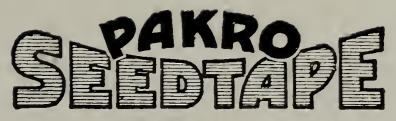

FOR BETTER GARDENS

\section{A Better as Well as an Easier Way}

Pakro Seedtape consists of seeds spaced in a thin paper tape. You just plant this tape a whole row at a time as fast as you can walk. It is not only easier to plant but it produces a better garden. The following reasons explain why.

1. Only the highest quality of thoroughly tested seeds is used - every variety is grown especially for Pakro and is selected by experts from the very best of prize winning strains.

2. Since you can plant a whole row at a time instead of a few seeds you can save a great amount of time and hard work-and besides you are assured of fine straight rows and an even stand

3. Pakro is more economical because you use only enough seed to insure a proper growth-with the smaller varieties of loose seed you plant much more than is necessary with the result that the plants are frequentlv over-crowded, slowgrowing and stunted.

4. In Pakro each variety of seed is spaced in the tape the correct distance apart. Therefore, the necessity of thinning out is practically done away with.

5. The paper tape absorbs and holds moisture around the seed which naturally results in a quicker and much higher percentage of germination and a stronger, healthier plant life.

These statements are taken from actual experience with Seedtape by thousands of home gardeners and many agricultural experts and experiment stations.

A few of these experiences are told on the opposite page. Read them! You already realize that Pakro is surely an easier, better way for you to plant your garden. These people have tried and tested it for you and have proved that it is a more desirable method.

Make Your Garden a Pakro Garden This Year 


\section{How to Plant}

\section{S PAKRo}

FOR BETTER GARDENS

Be sure to read very carefully the cultural directions printed on each individual box of Pakro and plant each variety according to the directions given.

The most common error is planting too deep.

Make a furrow of the proper depth according to the directions on the package and then lay the tape in tha furrow. Next thoroughly wet the tape in the furrow, but do not cover it with earth, until the surplus water has drained into the ground. Then cover the tape with earth, pressing the earth down fairly well by treading along the row.

Best results come from well prepared soil. A good program is as follows. First, cover it with well-rotted barnyard manure that has been kept under cover where rains have not leached the valuable ammonia content away from it. Turn this under with a spade or fork, mixing it deep and well so as to make the soil light and crumbly so that it is possible for air to get to the growing roots. Then it is a splendid idea to spread a top dressing of a well balanced commercial fertilizer-such as Bone Meal. This you can get from your dealer or from the fertilizer manufacturers and is inexpensive but wonderfully beneficial to the plant life.

After this is done you are ready for a Pakro Garden that you will be proud of.

\section{How to Order}

Pakro Seedtape comes in 30 varieties of vegetables and 18 varieties of flowers.

There are 40 feet of Pakro in every package of vegetables and 10 feet in every package of flowers.

The price of each package, whether vegetables or flowers, is 10 cents.

Select the number of packages of each variety that you wish on the order form enclosed and send it to us. Please be sure to send your money in the form of either a Post Office or Express Money Order.

Upon receipt of your order we will ship your Pakro immediately with all shipping charges prepaid.

Please mark your order plainly and use, preferably, pen and ink, and mention your local dealer's name. 


\section{BEET}

Crimson Globe

A wonderfully smoothskinned, perfectly shaped beet of medium size with deep crimson, fine grained flesh. The leaves grow compactly and are therefore easily removed. A very popular, second early variety that remains tender for a long time.
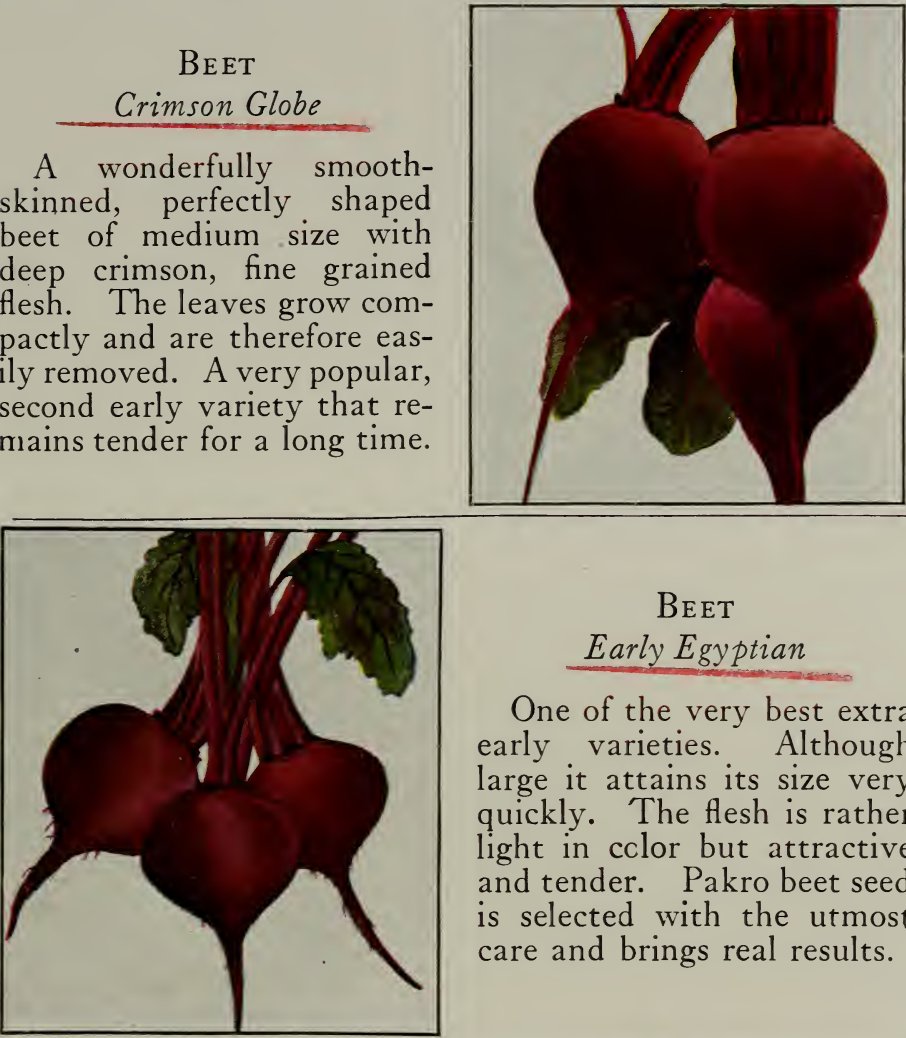

\section{Celery}

\section{White Plume}

The most attractive of all celerys, unsurpassed for fall and winter use. It grows so easily from Pakro Seedtape, requires so little earthing up to blanch the stalks, and is of such excellent flavor and crisp tenderness, that it should be included in every garden.

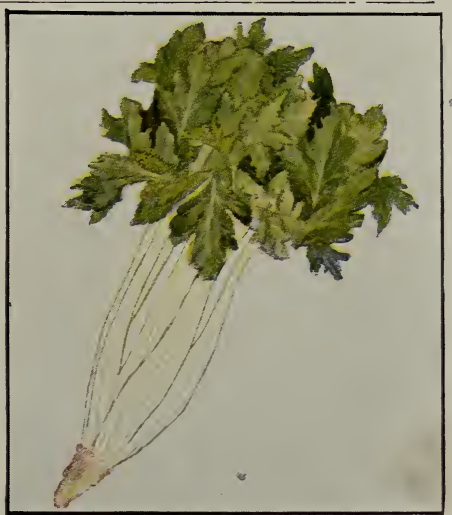




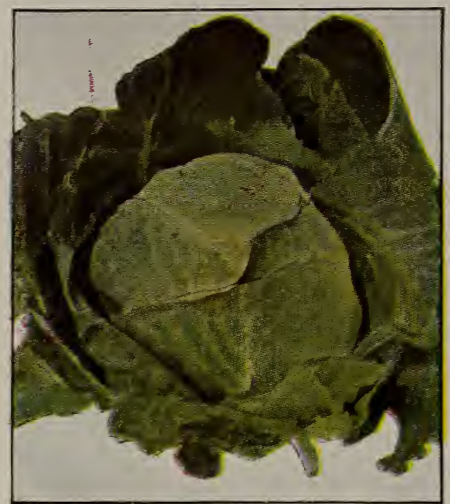

CabBage

All Seasons

An unusually large drum head variety of excellent quality; equally good for early spring, summer or fall use. Without doubt the best allround cabbage grown. Grow it once from Seedtape and you will never leave it out of your garden plan.

CabBage

Early Jersey Wakefield

The very best first early cabbage grown. Conical (pointed) in shape, attractive in appearance, delicate in flavor and the most palatable cabbage of all. The crop grown from the Pakro strain of seed may be depended upon for earliness, size and quality.
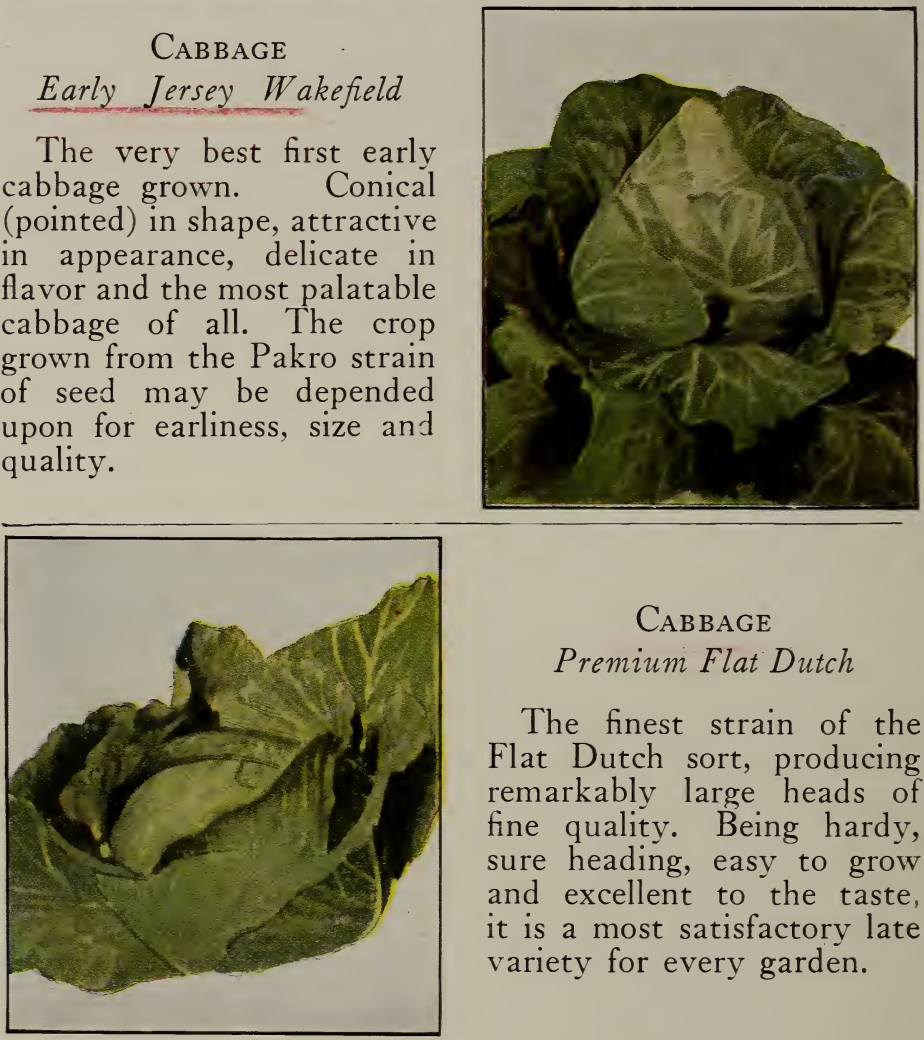

\section{CABBAgE \\ Premium Flat Dutch}

The finest strain of the Flat Dutch sort, producing remarkably large heads of fine quality. Being hardy, sure heading, easy to grow and excellent to the taste, it is a most satisfactory late variety for every garden. 


\section{Carrot \\ Danvers}

A smooth, rich orange-red, large growing variety with tops of medium size, roots that taper slightly to a blunt point, and flesh of fine close texture with but little core. Does well in all kinds of soil, is easier to harvest than the longer sorts, and is excellent for winter storing.
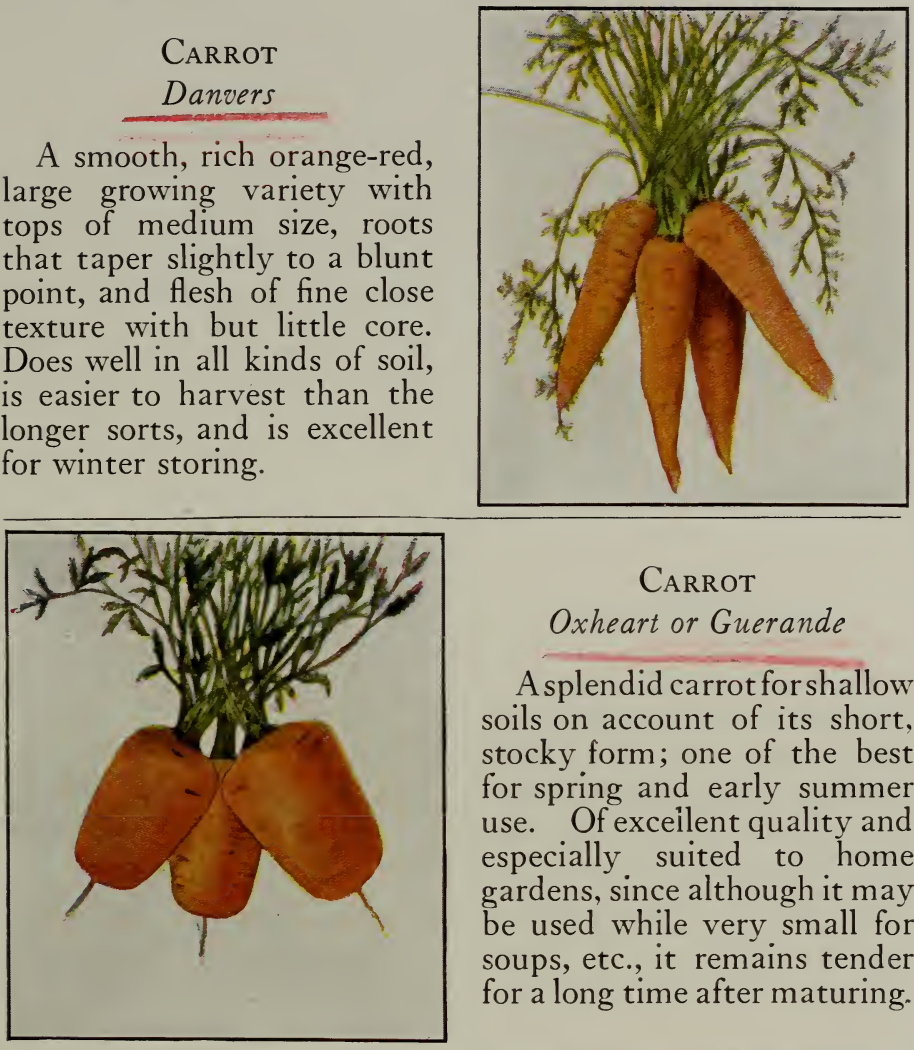

\section{CARRot \\ Oxheart or Guerande}

A splendid carrot for shallow soils on account of its short, stocky form; one of the best for spring and early summer use. Of exceilent quality and especially suited to home gardens, since although it may be used while very small for soups, etc., it remains tender for a long time after maturing.

\section{ENDIVE \\ Green Curled}

The standard variety for general use. Easily blanched by tying up the outside leaves or covering the plants with boards. We offer this variety only, because it is the best, the most easily grown and blanched, and of pleasant stimulating flavor.

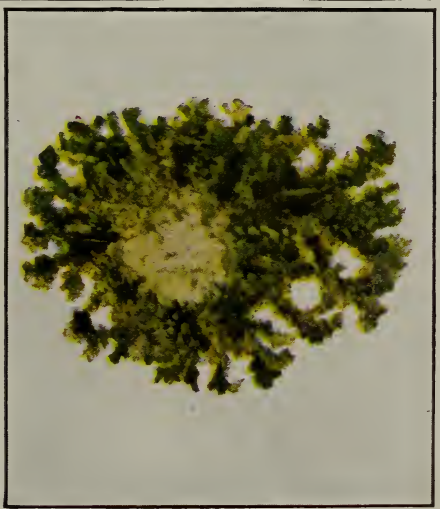




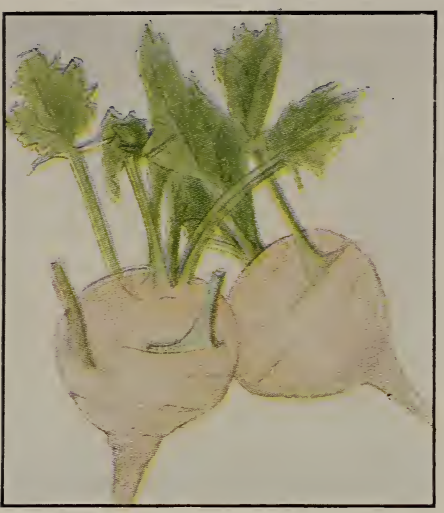

\section{KohlRabi}

Early White Vienna

This variety having a short top and forming the ball or tuber very quickly is well adapted to both home and market garden use. It may be pared and eaten raw; or sliced, boiled and served with a cream sauce.

\section{LEEK \\ Large Flag}

The best variety for general use, being mild and very popular. Young plants make excellent "scallions." Pakro Seedtape eliminates the usual difficulty of growing such vegetables as the leek, which must not be crowded.
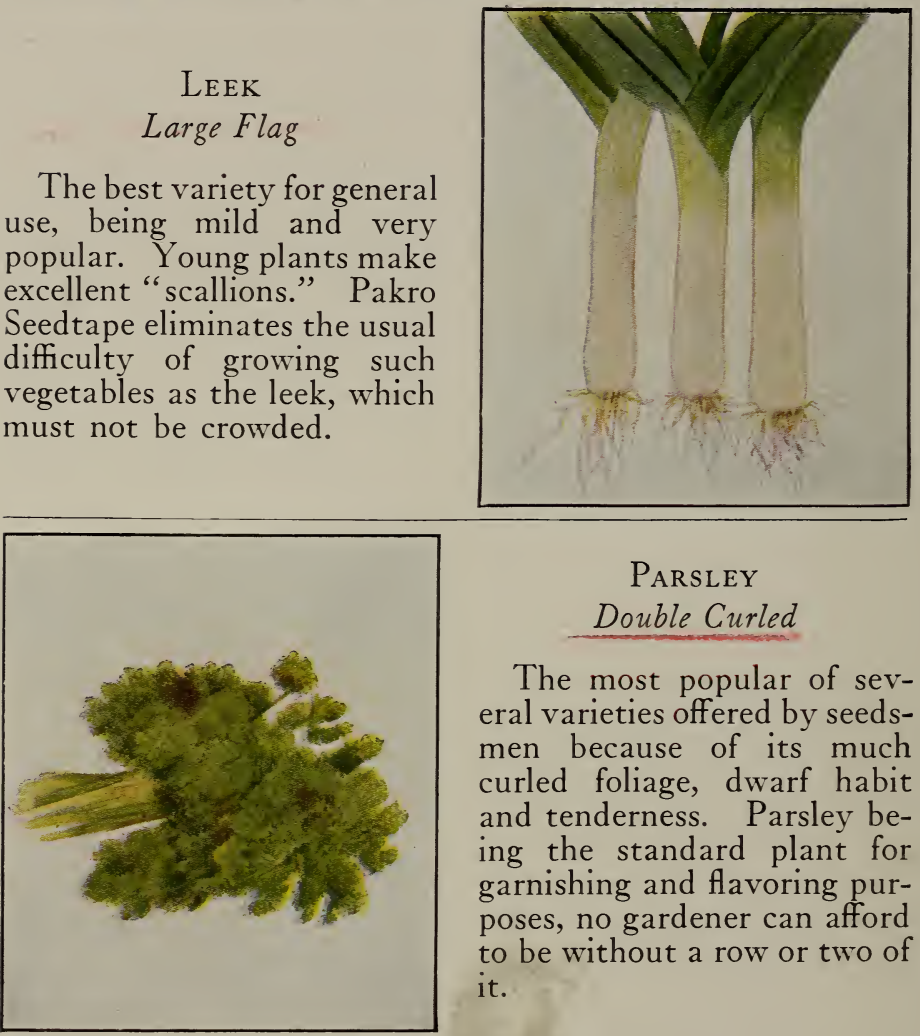

\section{Parsley \\ Double Curled}

The most popular of several varieties offered by seedsmen because of its much curled foliage, dwarf habit and tenderness. Parsley being the standard plant for garnishing and flavoring purposes, no gardener can afford to be without a row or two of it. 


\section{Lettuce \\ Big.Boston}

Without doubt the most popular lettuce grown. $\mathrm{Pa}$ kro Seedtape gives the utmost satisfaction, producing large, solid, creamy white heads, delightfully crisp and tender. This variety should be grown in early spring or late fall as it does not do well during hot, summer weather.
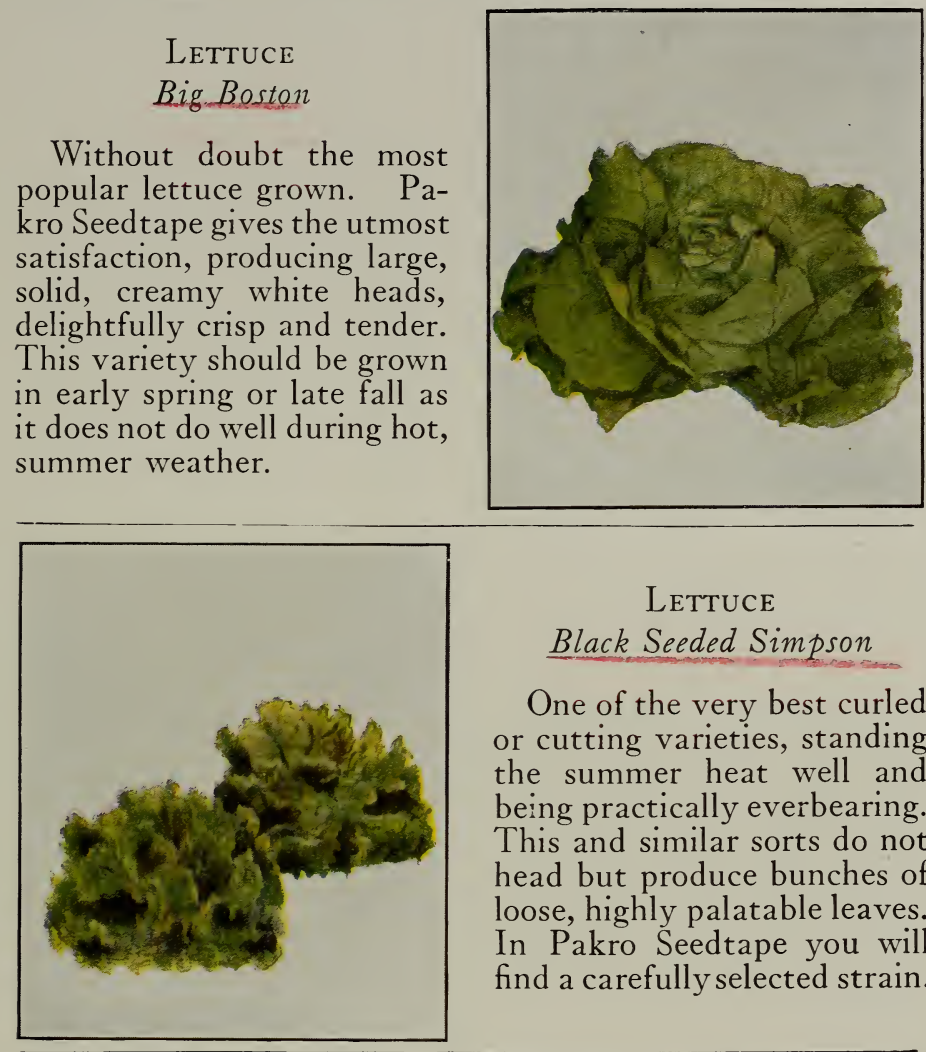

\section{LetTuce}

Black Seeded Simpson

One of the very best curled or cutting varieties, standing the summer heat well and being practically everbearing. This and similar sorts do not head but produce bunches of loose, highly palatable leaves. In Pakro Seedtape you will find a carefully selected strain.

\section{LetTuce \\ Trianon Cos}

The best variety of the distinct Cos or Romaine type which is much liked because of its crisp, tender quality and delicate flavor. It is easy to grow and may be blanched by tying up the outer leaves with raffia or soft string several days before the plant is wanted for the table.

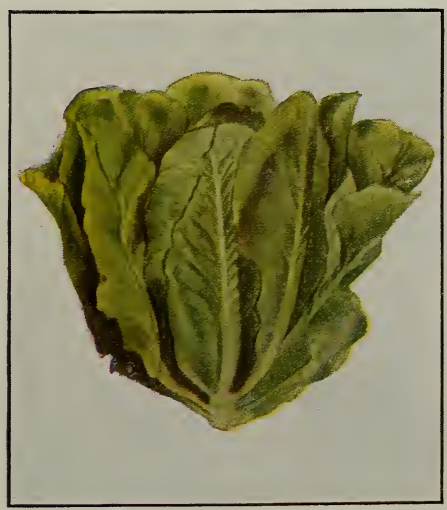




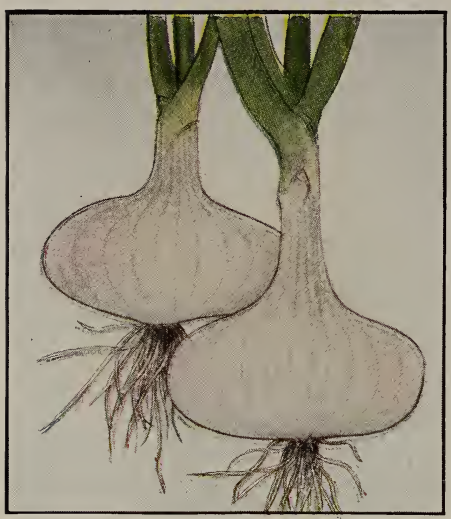

\section{ONION \\ White Portugal}

The leading white sort, of fine shape and mild flavor. It matures early, is excellent for pickling and, without doubt, is the best onion for general use. The seed is of the characteristic Pakro quality.

\section{ONION \\ Yellow Globe Danvers}

The best main crop variety and probably one of the oldest. Known as the "onion that never changes." An unusually good keeper of fine shape and uniformity and a general favorite everywhere. Like the other Pakro varieties this seed is from a carefully selected strain.
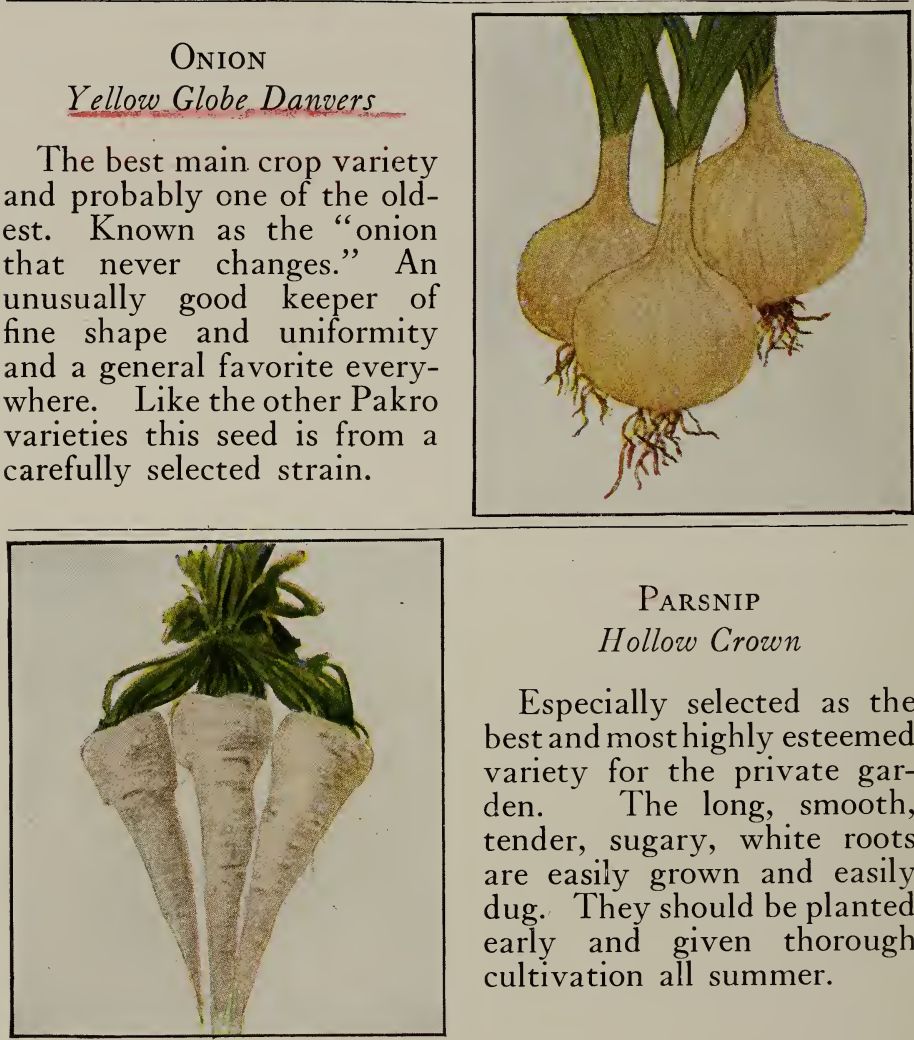

\section{PARSNIP \\ Hollow Crown}

Especially selected as the best and most highly esteemed variety for the private garden. The long, smooth, tender, sugary, white roots are easily grown and easily dug. They should be planted early and given thorough cultivation all summer. 


\section{PePper Bell or Bull Nose}

An early variety producing large, bright red, thick fleshed mildly flavored fruits. These are excellent while green for stuffing, and when ripe are unequalled for pickling and mild enough to be eaten raw. Surely this is the one pepper for all purposes.
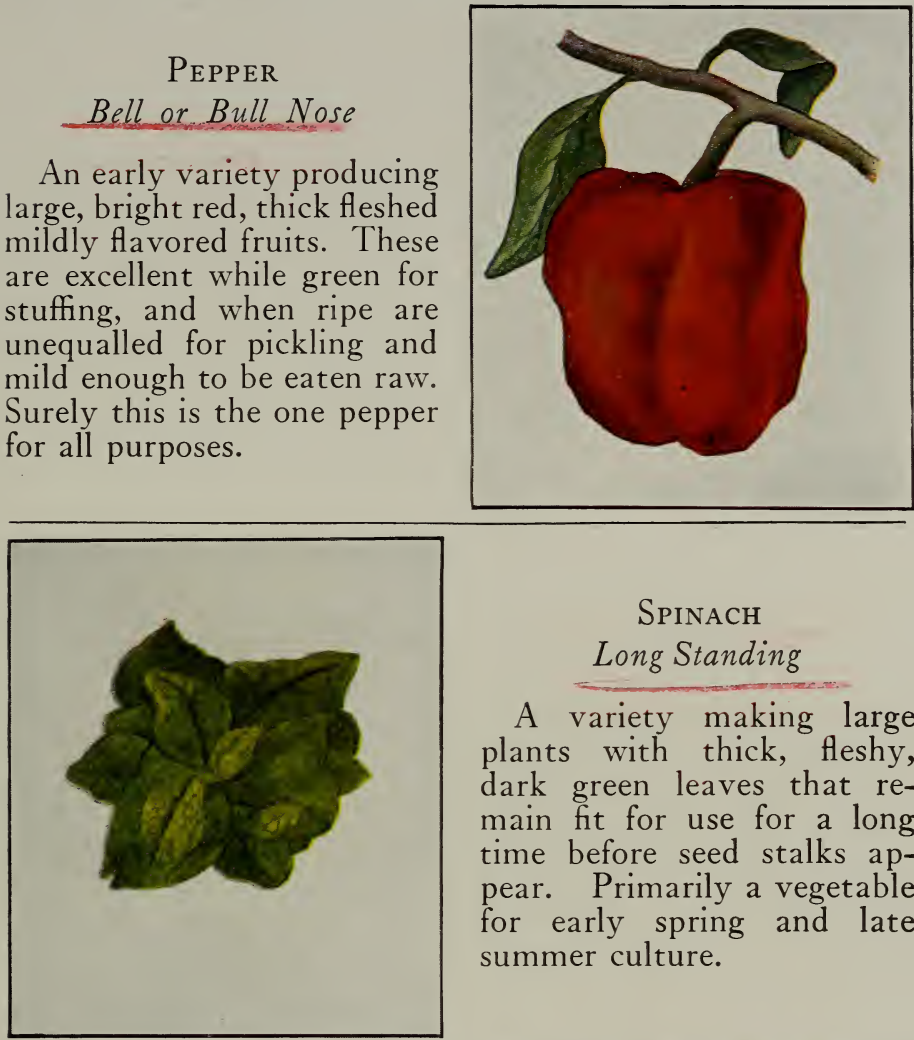

SPINACH

Long Standing

A variety making large plants with thick, fleshy, dark green leaves that remain fit for use for a long time before seed stalks appear. Primarily a vegetable for early spring and late summer culture.

\section{Swiss Chard}

One of the most delicious and convenient of "greens." Grows all summer giving frequent cuttings of succulent leaves. These may be boiled like spinach, or the leaf stalks may be prepared like asparagus, providing an excellent substitute. Any one can grow it from Pakro Seedtape-and everyone should.

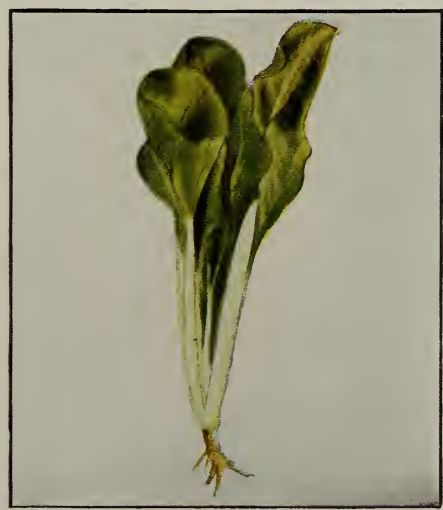




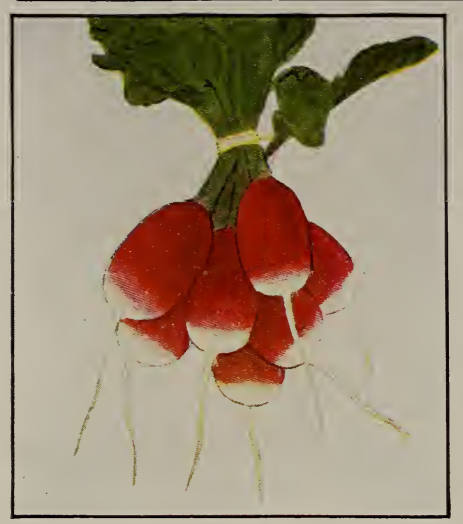

\section{RADIsH \\ French Breakfast}

Pakro Seedtape radishes have given such satisfaction that we found it necessary to increase our offering of varieties, and selected this sort as the most popular of the oval sorts. It is bright scarlet with a white tip, mild, very tender and a general family favorite.

RADISH

Icicle

A long, almost transparent white variety, crisp and brittle. It remains in fine condition for a long time and may be grown throughout the summer, thus enabling one to have fresh radishes all season.

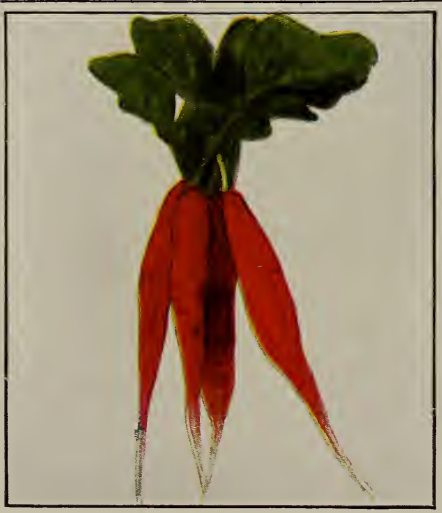

\section{RADISH \\ Long Scarlet}

The most popular long, red radish grown. The flesh is pure white, very crisp and exceedingly mild. Can be used equally well when very young and when fully mature. No first class garden is without a generous share of radishes. 


\section{RADISH}

Scarlet Turnip White Tip

Positively the most popular radish of all. Round, of medium size, in color a brilliant scarlet tipped with white, the flesh solid, pure white, crisp and mild-on the whole this variety is most attractive in appearance and unsurpassed for table use.
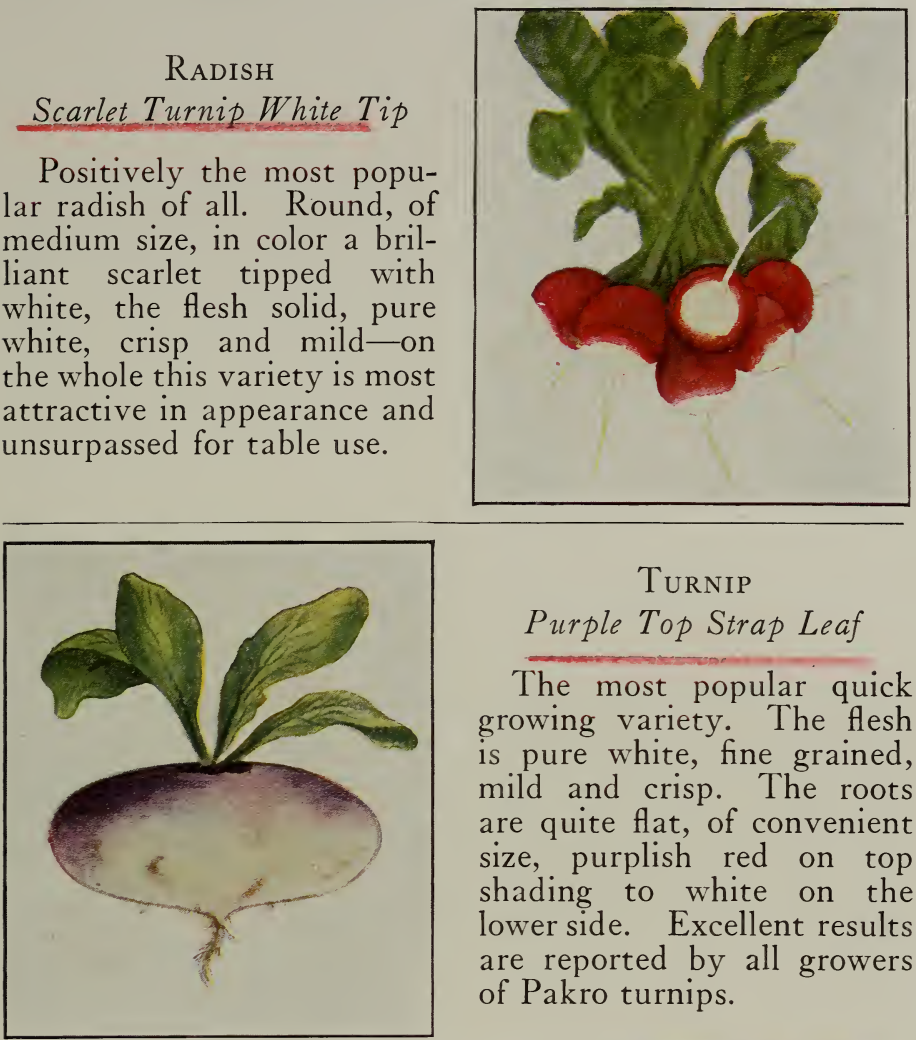

\section{TURNIP \\ Purple Top Strap Leaf}

The most popular quick growing variety. The flesh is pure white, fine grained, mild and crisp. The roots are quite flat, of convenient size, purplish red on top shading to white on the lower side. Excellent results are reported by all growers of Pakro turnips.

\section{Turnip}

\section{Purple Top White Globe}

An early, heavy yielding variety and a good keeper. The roots are large, globe shaped, white, shading to a reddish purple top, with fine grained, crisp white flesh. An excellent sort to grow for winter use. Like that of all Pakro vegetables, the seed is of the very highest quality.

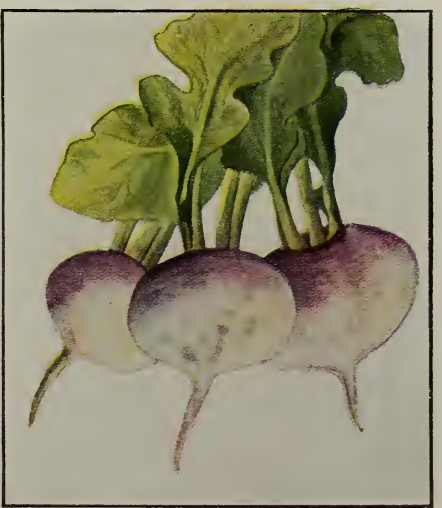




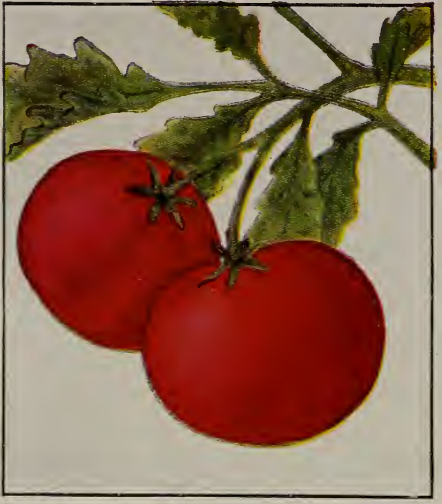

\section{Tomato}

\section{Beauty}

A well named variety, the fruit being of a glossy, crimson color with slight purplish tinge, of good size, of solid, meaty texture, and smooth. The plant is a strong grower and a very prolific bearer. Who could ask for more?

\section{Tomato}

Ponderosa

A tall, strongly growing variety producing fruits that often weigh two pounds or more apiece. These are purplish pink in color and, being unusually solid and containing very few seeds, are excellent for slicing. They continue to ripen practically until frost.
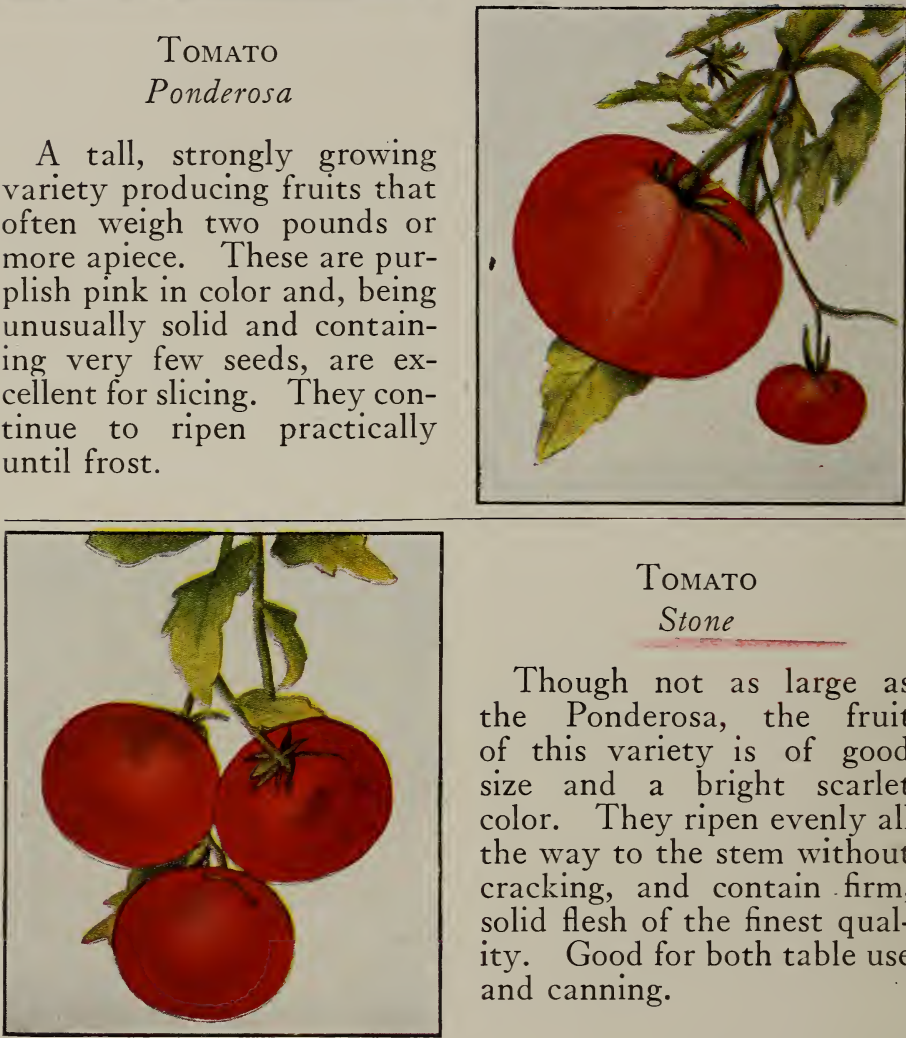

\section{Tомато}

\section{Stone}

Though not as large as the Ponderosa, the fruit of this variety is of good size and a bright scarlet color. They ripen evenly all the way to the stem without cracking, and contain firm, solid flesh of the finest quality. Good for both table use and canning. 


\section{Alyssum, Sweet}

The ever popular Sweet Alyssum, known by almost everyone needs little description. For beds, borders, baskets, etc., the dwarf plants with their all summer profusion of delicate, sweet scented white flowers are unexcelled.
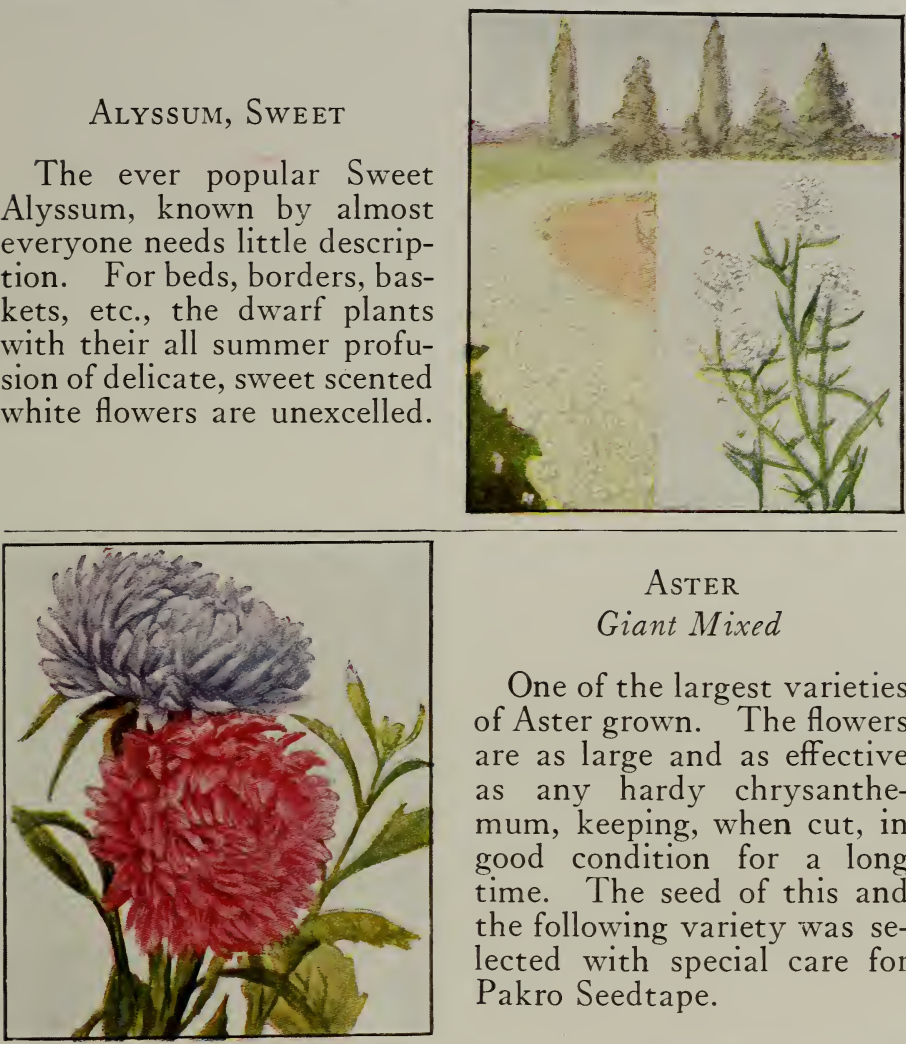

\section{Aster}

Giant Mixed

One of the largest varieties of Aster grown. The flowers are as large and as effective as any hardy chrysanthemum, keeping, when cut, in good condition for a long time. The seed of this and the following variety was selected with special care for Pakro Seedtape.

\section{Aster}

Queen of the Market, Mixed

An extremely early variety especially satisfactory as a source of cut flowers, the blooms being of medium size, double and long stemmed. The strongest plants come when each is given plenty of room; this is one reason for the success of Pakro Asters.

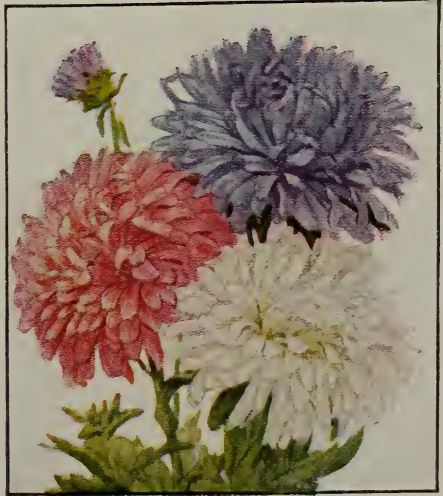




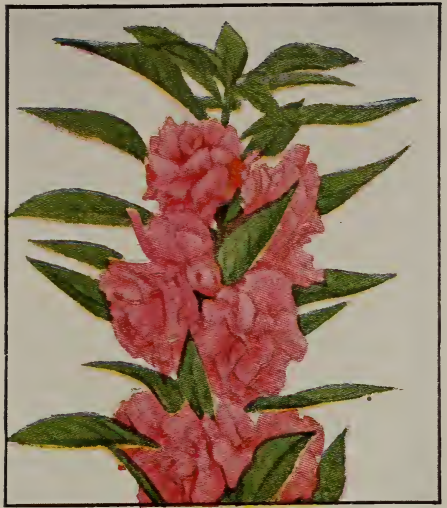

Balsam

Double Mixed

One of the most popular of the old-fashioned garden flowers, better known, perhaps, as Lady Slipper. Grows about two feet tall producing masses of brilliantly colored, very double flowers. Easily grown and a very satisfactory showy annual.

Candytuft Mixed

A dwarf flowering annual forming plants about a foot high. A very free bloomer usually considered indispensable for cutting purposes. For continuous bloom make successive plantings of Pakro Seed tape.
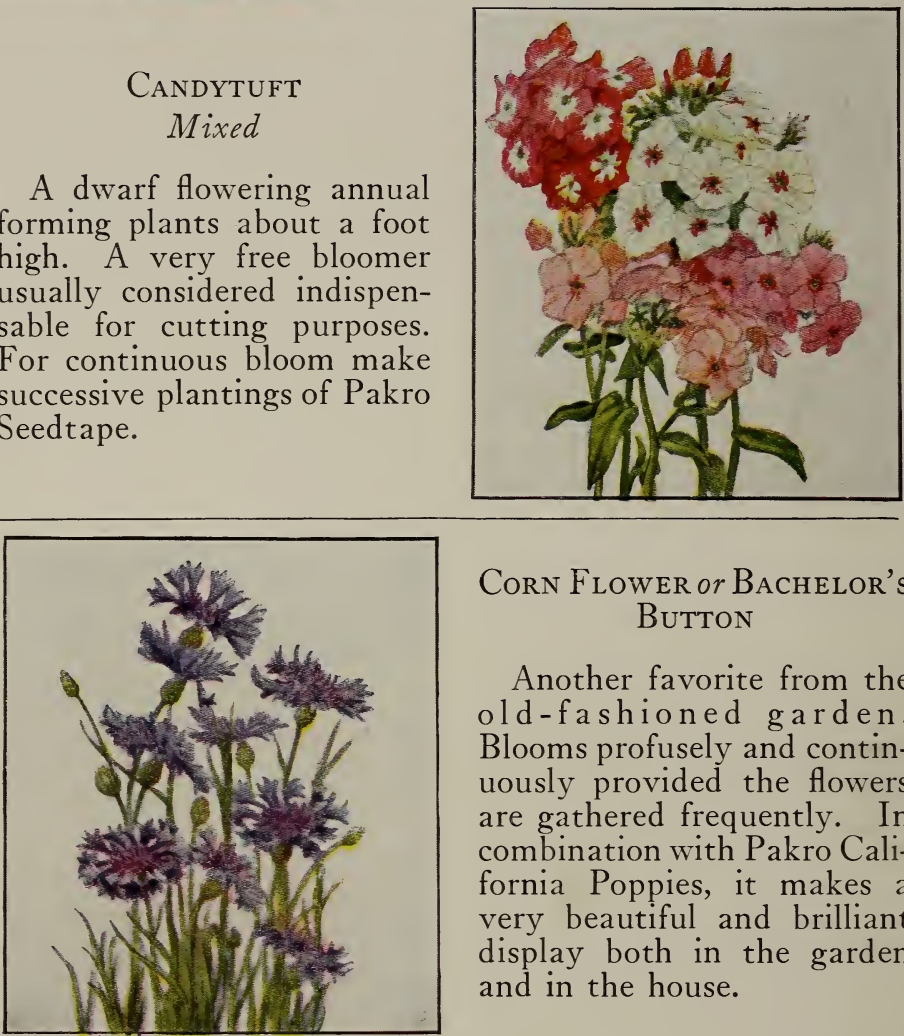

Corn Flower or BAchelor's BuTTON

Another favorite from the old-fashioned garden. Blooms profusely and continuously provided the flowers are gathered frequently. In combination with Pakro California Poppies, it makes a very beautiful and brilliant display both in the garden and in the house. 


\section{FoRGET-ME-NOT}

A perennial that blooms the first year if planted early. Especially effective if grown as a border. Provides a touch of bright and pleasing color in the spring when it is most welcome.

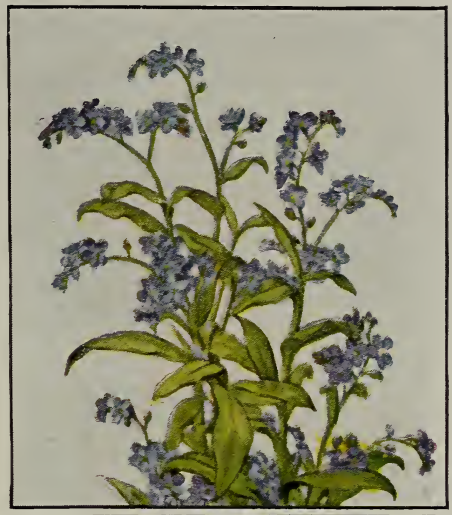

HollyHock

Chartier's Double Mixed

One of our forefathers' favorites that is still highly valued for planting among shrubbery, against walls and fences, and as a background for other smaller flowers. The strain selected for Pakro Seedtape is of the best, producing large, brilliant, very double flowers in great profusion.

\section{Mignonette}

Grandiflora

No garden is really complete without a bed of this popular, fragrant, free blooming annual. Successive plantings give a continuous supply of bloom from early spring until frost.

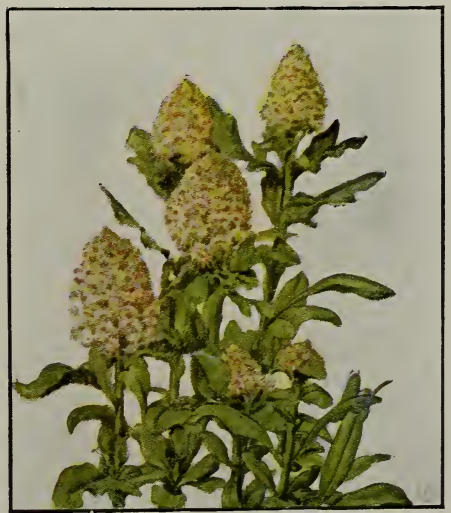




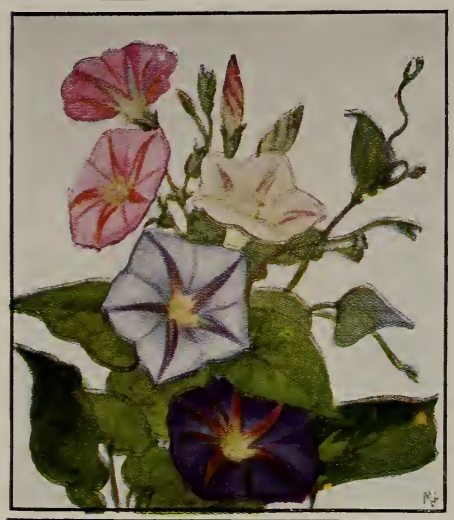

Morning GLORY

Selected Imperial Mixed

This is the imported giant Japanese variety that makes as much as thirty feet of growth in a season. The brilliant flowers are well known, but in this variety the foliage too is wonderfully effective before the blossoms appear. Use it for covering trellises, fences and walls, screening porches, etc.

\section{Pansies}

Good Mixed

In Pakro Seedtape we do not offer the ordinary mixed Pansies, but the very best strain that can be secured, one that produces large varicolored flowers beautifully marked and mottled, in great profusion.
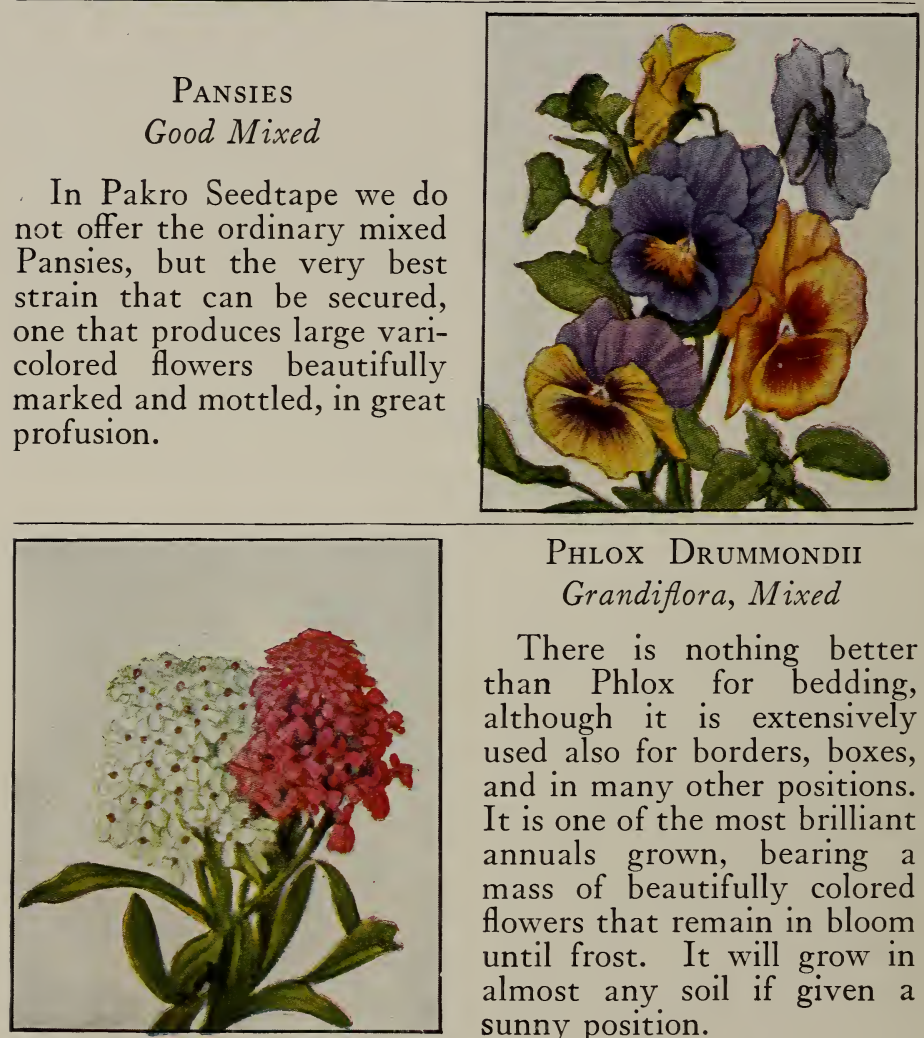

Phlox Drummondi

Grandiflora, Mixed

There is nothing better than Phlox for bedding, although it is extensively used also for borders, boxes, and in many other positions. It is one of the most brilliant annuals grown, bearing a mass of beautifully colored flowers that remain in bloom until frost. It will grow in almost any. soil if given a sunny position. 


\section{Pinks \\ Double, Mixed}

One of the most popular flowers in cultivation producing many blossoms of varied, brilliant colors a short time after planting and continuously up to cold weather. The double varieties we offer resemble small carnations and are fine for cutting.
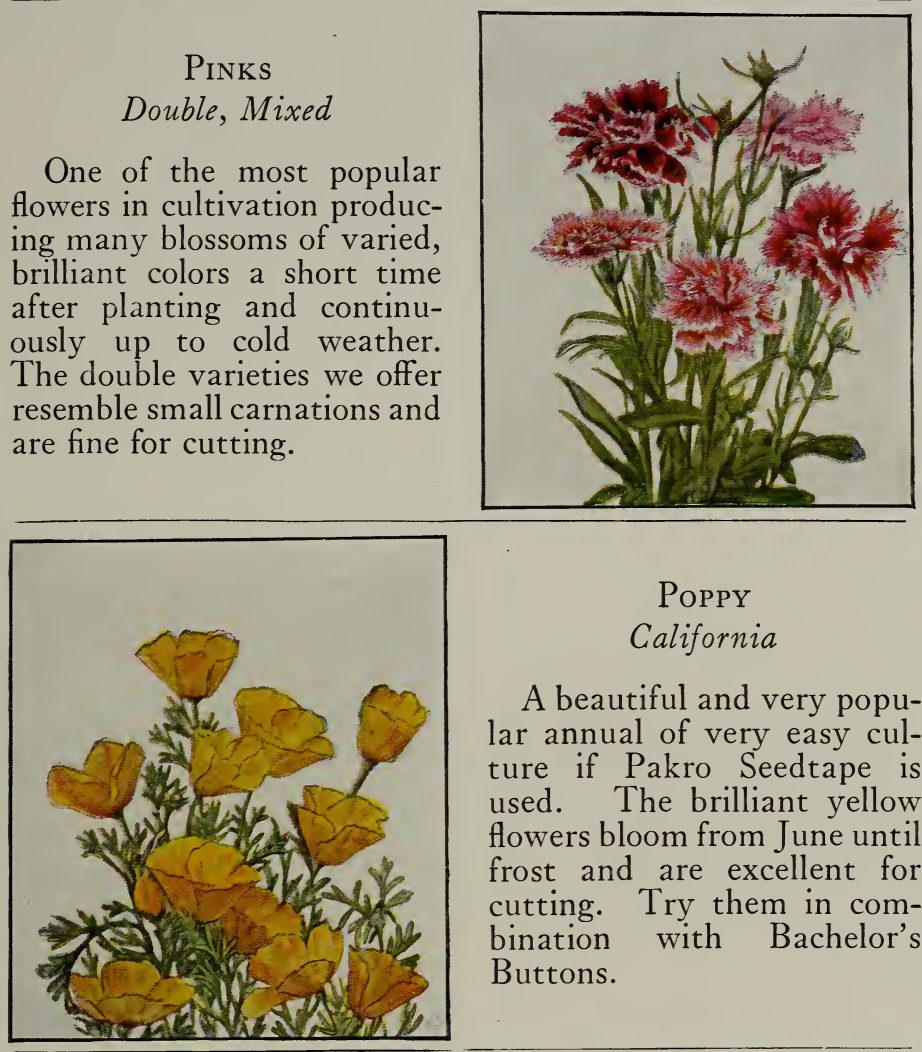

\section{Poppy \\ California}

A beautiful and very popular annual of very easy culture if Pakro Seedtape is used. The brilliant yellow flowers bloom from June until frost and are excellent for cutting. Try them in combination with Bachelor's Buttons.

POPPY

Shirley, Mixed

One of the most attractive varieties grown, producing wonderful flowers, ranging from the purest white through pink, rose and carmine, to the deepest crimson. This sort blooms continuously for a long time.

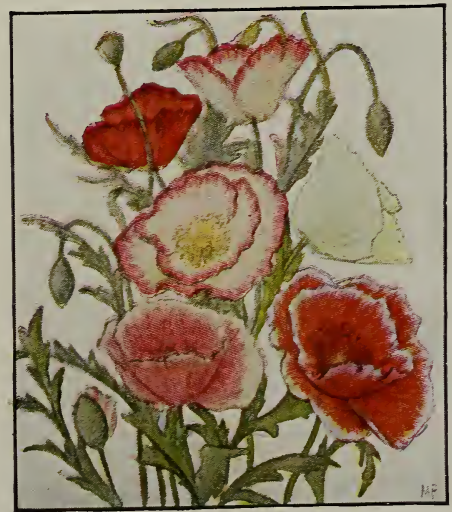




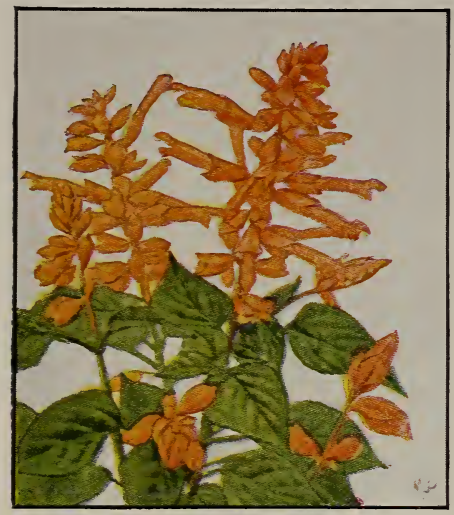

\section{Salvia Splendens Grandiflora}

The Scarlet Sage, as this plant is also known, has long been a favorite, especially for use with masses of foliage plants and against building foundations. During the summer and fall it produces striking scarlet flowers in great profusion on long stems or spikes.

STOcks

Ten Weeks, Mixed

The earliest flowering variety, therefore the favorite for bedding. It produces fragrant flowers of great beauty on tall spikes much like the Hollyhock. Plants grown from Pakro Seedtape are sure to give satisfaction.
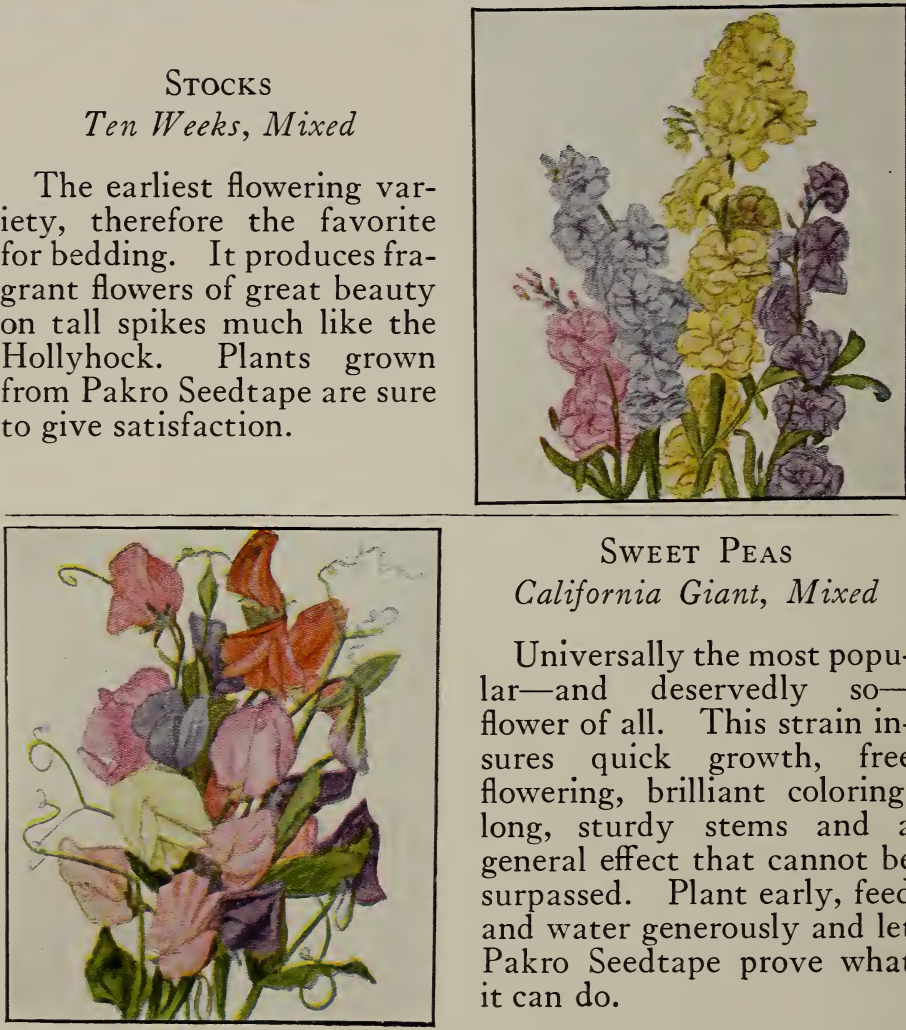

Sweet Peas

California Giant, Mixed

Universally the most popular-and deservedly soflower of all. This strain insures quick growth, free flowering, brilliant coloring, long, sturdy stems and a general effect that cannot be surpassed. Plant early, feed and water generously and let Pakro Seedtape prove what it can do. 


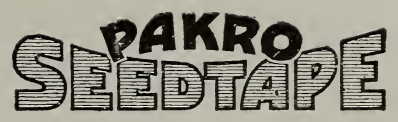

FOR BETTER GARDENS

\section{Special Introductory Collections}

We will send you, all shipping charges prepaid, upon receipt of the amount mentioned in currency or money order, any of the collections below.

Thesecollections are especially recommended by our Gardening Experts, who have had years of experience in laying out both large and small gardens. Select one of these collections and you will be assured of a well balanced garden which will result in a continuous supply of fresh vegetables and flowers throughout the season.

\section{COLLECTION A, $\$ 1.00$}

\section{PAKRO SEEDTAPE}

$40 \mathrm{ft}$. No. 2 Beet, Egyptian.

40 “ “ 6 Cabbage, Jersey Wakefield. 40 “ “ 31 Parsley, Double Curled.

40 “ “ 11 Carrot, Oxheart. 40 “ “ 40 Radish, Scarlet Turnip

40 “ “ 22 Lettuce, Big Boston. White Tip.

\section{PAKRO SELECTED SEED (not taped)}

1 Pkg. 202 Beans, Improved Golden Wax. | 1 Pkg. 212 Corn, Golden Bantam.

1 “ 200 Beans, Bountiful.

\section{COLLECTION B, $\$ 1.00$}

\section{PAKRO SEEDTAPE}

$40 \mathrm{ft}$. No. 1 Beet, Crimson Globe.

40 “" " 10 Carrot, Danvers.

40 “" “ 23 Lettuce, Black Seeded Simpson.
$40 \mathrm{ft}$. No. 43 Spinach, Long Standing.

10 “ “ 101 Aster, Giant Mixed.

10 “ “ 108 Mignonette.

10 “ “ 114 Pinks, Double Mixed.

\section{PAKRO SELECTED SEED (not taped)}

1.Pkg. No. 203 Beans, Refugee Wax.

1 “ " 212 Corn, Golden Bantam.
$1 \mathrm{Pkg}$. No. 211 Cucumber, Cool and Crisp 1 “" “ 221 Nasturtium, Dwarf Mixed 


\section{COLLECTION C, $\$ 2.50$}

\section{PAKRO SEEDTAPE}

40 ft. No. 5 Cabbage, All Seasons.

40 “ “ 11 Carrots, Oxheart.

40 “ “ 14 Celery, White Plume.

40 “ “ 16 Endive, Green Curled.

40 ““ “ 18 Kohlrabi, White Vienna.

40 “. . 24 Lettuce, Trianon Cos.

40 “ “ 27 Onion, White Portugal.

40 “ “ 53 Turnip, Purple Top Strap Leaf.

10 “ “ 100 Sweet Alyssum.

10 “ " 101 Aster, Queen of the Market.

10 “ “ 103 Balsam, Double Mixed.
$40 \mathrm{ft}$. No. 31 Parsley, Double Curled.

40 “ “ 33 Parsnips, Hollow Crown.

40 “ “ 37 Radish, French Breakfast.

40 “ “ 38 Radish, White Icicle.

40 “ “ 43 Spinach, Long Standing.

40 “ “ 4ô Swiss Chard, Giant Lucullus.

10 “ “ 104 Candytuft, Mixed.

10 “" " 105 Corn Flower, (Bachelor Button).

10 “ “ 106 Forget-me-not, Blue.

10 “ “ 112 Pansies, Good Mixed.

\section{PAKRO SELECTED SEED (not taped)}

$1 \mathrm{Pkg}$. Beans, Refugee Wax.

1 “ Beans, Burpee's Bush Lima.

1 “ Peas, Gradus.

1 Pkg. Cucumber, Imp. White Spine. 1 “ Musk Melon, Rocky Ford.

\section{COLLECTION D, $\$ 5.00$}

\section{PAKRO SEEDTAPE}

$40 \mathrm{ft}$. No. 1 Beet, Crimson Globe.

40 “ “ 2 Beet, Egyptian.

40 “ “ 5 Cabbage, All Seasons.

40 “ “ 10 Carrot, Danvers.

40 “" “ 11 Carrot, Oxheart.

40 “ “ 16 Endive, Green Curled.

40 “ “ 18 Kohl Rabi, White Vienna.

40 “ “ 20 Leek, Large Flag.

40 “ “ 22 Lettuce, Big Boston.

40 “ “ 23 Lettuce, Black Seeded Simpson.

40 “ “ 24 Lettuce, Trianon Cos.

40 “ “ 27 Onion, White Portugal.

40 “ “ 28 Onion, Yellow Globe.

40 “ “ 31 Parsley, Double Curled.

40 “" “ 33 Parsnip, Hollow Crown.

40 “ “ 37 Radish, French Breakfast.

40 “ " 38 Radish, Icicle.

40 “ “ 39 Radish, Long Scarlet.
$40 \mathrm{ft}$. No. 40 Radish, Scarlet Turnip White Tip.

40 “ “ 43 Spinach, Long Standing.

40 “ “ 46 Swiss Chard, Giant Lucullus.

40 “ “ 53 Turnip, Purple Top Strap Leaf.

10 “ “ 101 Aster, Queen of the Market.

10 “ “ 103 Balsam, Double Mixed.

10 “" " 104 Candytuft, Mixed.

10 “ " 109 Morning Glory, Mixed.

10 “ “ 112 Pansies, Good Mixed.

10 “ “ 113 Phlox, Drummondii; Mixed.

10 “ “ 114 Pinks, Double Mixed.

10 “ " 115 Poppy, California.

20 “ “ 119 Sweet Peas, Mixed.

\section{PAKRO SELECTED SEED (not taped)}

$\frac{1}{2}$ Pt. No. 200 Beans, Bountiful.

$\frac{1}{2}$ “ “ 201 Beans, Early Red Valentine.

$\frac{1}{2}$ “ “ 202 Beans, Improved Golden Wax.

$\frac{1}{2}$ “ “ 205 Beans, Burpee's Bush Lima.

$\frac{1}{2}$ “ “ 212 Corn, Golden Bantam.

$\frac{1}{2}$ “ “ 213 Corn, Country Gentle-
$1 \mathrm{Pkg}$. No. 220 Nasturtium, Tall Mixed.

1 “ “ 221 Nasturtium, D war f Mixed.

$1 \mathrm{Oz}$. “ 211 Cucumber, Cool and Crisp.

1 Pkg. “ 215 Musk Melon, Rocky Ford.

1 “ “ 218 Squash, True Hubbard.

$1 \mathrm{Pt}$. “ 206 Peas, Gradus.

1 “ “ 208 Peas, Notts' Excelsio: 


\section{PAKRO BRAND}

\section{Specially Grown Garden Seed (Loose)}

\section{BEANS DWARF-GREEN PODDED}

No.

200

201
Beans, Bountiful. Early, broad fleshy variety Beans, Extra Early Red Valentine-of excellent quality.................
Packet $\frac{1}{2} \mathrm{Pt}$. $\quad \mathrm{Pt}$

$\$ .10 \$ .15 \$ .25$

$.10 \quad .15 \quad .20$

\section{BEANS DWARF-WAX PODDED}

202 Beans, Improved Golden Wax. Full round Stringless pods of fine quality...........

203 Beans, Refugee Wax, extremely productive

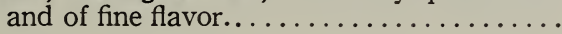

$\begin{array}{lll}.10 & .20 & .30 \\ .10 & .20 & .30\end{array}$

\section{BEANS-LIMA}

204 Beans, Challenger Pole Lima. Very productive, thick tender beans................

205 Beans, Burpee's Bush Lima. Excellent Dwarf variety of fine flavor. ................

\section{PEAS}

206 Peas, Gradus. Tall. Extra Early. Pods filled with large tender wrinkled peas. ..........

207 Peas, English Wonder. Early Dwarf. Very productive with a sweet flavor...........

208 Peas, Notts' Excelsior. Early Dwarf. Large podded, productive variety.............

209 Peas, Telephone. Tall, Late. One of the best varieties grown, producing large filled pods. .

$\begin{array}{lll}.10 & .15 & .25\end{array}$

$.10 \quad .15 \quad .25$

$\begin{array}{lll}.10 & .15 & .25\end{array}$

$.10 \quad .15 \quad .25$

\section{CUCUMBER}

210 Cucumber, Improved White Spine. Early variety, producing crisp tender cucumbers. .

211 Cucumber, Cool and Crisp. Long variety, tender and crisp, bears for a long time .....

\section{SWEET CORN}

212 Corn, Golden Bantam. One of the finest varieties grown, sweet, tender. Well filled ears

213 Corn, Country Gentleman. Deep grains, deliciously sweet and tender. ...............

Packet $\mathrm{Oz}$.

$.05 \quad .15$

$.05 \quad .15$

Packet $\frac{1}{2}$ Pt. Pt.

$\begin{array}{lll}.10 & .20 & .30\end{array}$

$\begin{array}{lll}.10 & .15 & .25\end{array}$ 


\section{MUSK MELON}

No.

214 Musk Melon, Extra Early Hackensack. Very early sweet juicy variety.................

215 Musk Melon, Rocky Ford. Thick meaty excellent flavored variety..............

\section{WATER MELON}

216 Water Melon, Coles' Early. Medium size, with large heart of fine texture............... . . $05 \quad .10$

217 Water Melon, Sweetheart. Flesh bright red, very

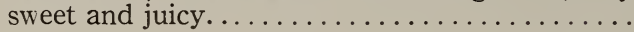

\section{SQUASH}

218 Squash, True Hubbard. Late running variety, excellent for pies.

219 Squash, Long Island White Bush. Early bush variety, fine grain and flavor. ............ .0. . 05

\section{NASTURTIUM}

220 Nasturtium, Tall Mixed. Quick climber for trellis, fences, etc...................... .05 .10

221 Nasturtium, Dwarf Mixed. Beautiful effect on . rockeries, or borders................. .05 . 10 


\section{Even If You Have Nothing More}

Than a Back Yard-Grow

\section{Vegetables This Year}

7 The steadily mounting cost of food products is a serious problem that affects every family in the land. Almost every family is looking about for a way to solve this problem and secure the needed and usual quantity of vegetables at a price within its means.

NI One of the best ways of solving your high cost of living problem is to put whatever ground you may have to work growing vegetables for you, and even though you have nothing bigger than a city back yard, the ground can be made to produce fine fresh vegetables at an insignificant cost, and the pleasure and good healthy outdoor work that it will bring to you will be an additional benefit that you will appreciate keenly.

Tा Save money, reduce your living expenses, and add to your pleasures this Spring and Summer-have a Pakro Seedtape garden. And don't forget that Pakro Flowers and Vegetables germinate quicker, develop stronger, healthier plants and more abundant, gloriously beautiful flowers. 
Horace sud o string Co Chicago del. mile. 